\title{
ANALISIS SISTEM INFORMASI AKUNTANSI PENERIMAAN DAN PENGELUARAN KAS PADA BADAN PENGELOLA KEUANGAN DAN ASET DAERAH (BPKAD) KOTA BAUBAU
}

\author{
Dwi Agustyawati \\ Program Studi Manajemen, Fakultas Ekonomi \\ Universitas Muhammadiyah Buton, Baubau, Indonesia \\ e-mail : partyazh@gmail.com
}

\begin{abstract}
ABSTRAK
Tujuan dari penelitian ini untuk mengetahui pelaksanaan sistem informasi akuntansi penerimaan dan pengeluaran kas pada Badan Pengelola Keuangan dan Aset Daerah Kota Baubau sesuai dengan peraturan yang berlaku. Teknik yang digunakan dalam penelitian ini adalah studi kepustakaan, wawancara dan dokumentasi. Sedangkan teknik analisis data yang digunakan adalah analisis deskriptif kualitatif.

Berdasarkan hasil penelitian diperoleh bahwa sistem penatausahaan penerimaan dan pengeluaran kas telah dilengkapi dengan dokumen, Surat Tanda Bukti Pembayaran, Surat Tanda Setor (STS) dan Nota Kredit telah sesuai dengan pemendagri No. 21 Tahun 2011. Selanjutnya sistem pengeluaran kas atas beban Anggaran Pendapatan dan Belanja Daerah (APBD) yang digunakan sudah sesuai dengan peraturan yang digunakan. Sistem dan prosedur pengeluaran kas di Badan Pengelola Keuangan dan Aset Daerah (BPKAD) Kota Baubau sudah efektif, hal ini dilihat dari penyelesaian Surat Perintah Membayar (SPM) yang masuk di Badan Pengelola Keuangan dan Aset Daerah Kota Baubau dapat dilakukan dalam jangka waktu 1 hari dengan memenuhi persyaratan yang telah ditentukan.
\end{abstract}

\section{Kata kunci : Sistem Informasi Akuntansi, Penerimaan Kas, Pengeluaran Kas}

\section{ABSTRACT}

The purpose of this study to determine the implementation of the Accounting Information System of Cash Receipts and Disbursements in Financial Management Bodies and Municipal Asset on Baubau City accordance with applicable regulations. The technique used in this research is the study of literature, interviews and documentation. While the data analysis technique used is qualitative description analysis.

Based on the results of the study, it wa found that the system for administering cash receipts and disbursements was completed with documents, proof of payment, deposit letter (STS) and credit note has been in accordance with the Minister of Home Affairs number 21 of 2011. Then the cash disbursement system at the expense of the regional income and expenditure budget used (APBD) is in accordance with the established regulations. The system and procedures for cash disbursement in the Financial Management and Asset (BPKAD) of the city of Baubau have been effective. This is seen from the completion of the payment warrant (SPM) that entered the Financial Management body and assets of the city area of Baubau can be done whitin one day by fukfikking the specified requirements.

Keywords : Accounting Information System, Cash Receipts,Cash Disbursement. 


\section{PENDAHULUAN}

Sejalan dengan pelaksanaan otonomi daerah, akuntansi sektor publik di Indonesia juga terus mengalami perkembangan. Akuntansi sektor publik dalam perkembangannya selain sebagai suatu sistem yang digunakan oleh pemerintah daerah dalam mengelola keuangan daerah juga digunakan sebagai bentuk pertanggungjawaban pemerintah kepada publik. Dalam hal pertanggungjawaban ini semakin besar perhatian publik terhadap praktek akuntansi yang dilakukan oleh lembaga-lembaga pemerintahan. Menurut Halim, akuntabilitas ialah kewajiban untuk memberikan pertanggungjawaban serta menerangkan kinerja dan tindakan seseorang, badan hokum atau pimpinan organisasi kepada pihak lain yang memiliki hak dan kewajiban untuk meminta kewajiban pertanggungjawaban dan keterangan [1].

Untuk mewujudkan suatu transparansi dan akuntabilitas dalam laporan keuangan pemerintah daerah harus memenuhi Standar Akuntansi Pemerintahan (SAP) sesuai dengan Peraturan Pemerintah Nomor 71 Tahun 2010. Mengingat laporan keuangan yang dihasilkan oleh pemerintah daerah akan digunakan sebagai dasar untuk pengambilan keputusan, suatu laporan keuangan pemerintah harus disajikan dan dilaporkan sesuai dengan Standar Akuntansi Pemerintah yang diterima umum. Sehingga dalam penyusunannya sangat diperlukan sistem akuntansi yang baik, yang dapat mendukung terciptanya laporan keuangan yang berkualitas yakni relevan, andal, dapat dibandingkan, dapat dipahami dan tetap mengutamakan transparan-transparansi dan akuntabilitas [2].Sistem akuntansi adalah formulir-formulir, catatan-catatan, prosedur-prosedur dan alat-alat yang digunakan untuk mengolah data yang berhubungan dengan suatu usaha kesatuan ekonomis bertujuan untuk umpan balik dalam bentuk laporan-laporan yang diperlukan oleh manajemen untuk mengawasi usahanya dan bagi pihak lainnya yang berkepentingan seperti pemegang saham, kreditur, dan lembaga-lembaga pemerintah untuk menilai hasil operasi [3]. Fungsi sistem informasi dalam transformasi data menjadi informasi yang akan digunakan dalam mendukung pengambilan keputusan oleh organisasi, dengan mengetengahkan dimensi pelaksana, data, proses, dan teknologi informasi [4].

Sistem informasi akuntansi merupakan kumpulan sumber daya, seperti manusia dan peralatan yang dirancang untuk mengubah data keuangan dan data lainnya ke dalam informasi, informasi tersebut dikomunikasikan kepada para pembuat keputusan [5].Pada saat Sistem Informasi Akuntansi (SIA) terintegrasi dengan teknologi informasi yang digunakan oleh organisasi tidak berjalan dengan baik, maka akan menghasilkan output informasi yang dapat melemahkan kinerja organisasi. Keberhasilan sistem informasi suatu organisasi tergantung bagaimana sistem itu dijalankan, kemudahan sistem itu bagi para pemakainya dan pemanfaatan teknologi yang digunakan. Pemerintah daerah memerlukan sistem yang dapat menghasilkan 
laporan keuangan dan informasi keuangan lainnya secara lebih komprehensif yang meliputi informasi mengenai posisi keuangan daerah, kondisi kinerja keuangan,dan akuntabilitas pemerintah daerah. Untuk itu pemerintah pusat dan pemerintah daerah dapat memanfaatkan dan mendayagunakan kemajuan teknologi informasi, sehingga laporan keuangan yang dihasilkan oleh pemerintah daerah dapat memenuhi kriteria nilai informasi yang disyaratkan.

Perubahan undang-undang memberikan dampak terhadap pengaturan sistem keuangan pada pemerintah di daerah. Dalam pengaturan sistem keuangan pemerintah, diperlukan adanya pengembangan sistem penyelenggaraan pemerintahan yang memanfaatkan kemajuan teknologi informasi pemerintah yang dapat dianalisis dan dimanfaatkan secara tepat, akurat dan aman. Salah satunya adalah Sistem Akuntansi Sektor Publik yang mencakup Akuntansi Pemerintahan. Sistem akuntansi pemerintahan saat ini telah banyak mengalami perkembangan, diikuti dengan adanya perubahan dasar hukum.

Akuntansi Pemerintah Daerah merupakan rangkaian proses yang dimulai dari pencatatan, penggolongan, serta pengiktisaran dengan cara yang telah ditentukan dalam ukuran moneter (dalam hal ini uang), dan transaksi atau kejadian-kejadian yang umumnya bersifat keuangan dan termasuk pelaporan hasil-hasilnya dalam penyelenggaraan urusan pemerintah menurut asas ekonomi dan tugas pembantuan dengan prinsip Negara Kesatuan Republik Indonesia [6].Prosedur pencatatan pada akuntansi pemerintahan dikelompokkan menjadi enam bagian yaitu pendapatan, belanja, pembiayaan, aset, kewajiban, dan ekuitas dana [7]. Sedangkan kegiatan akuntansi pada Satuan Kerja Perangkat Daerah (SKPD) meliputi pencatatan atas pendapatan, belanja, aset dan selain kas [8].

Penerimaan kas merupakan komponen sumber daya yang sangat penting didalam melaksanakan program pembangunan yang telah direncanakan oleh pemerintah baik pemerintah pusat maupun pemerintah daerah. Kas ialah uang tunai dan saldo simpanan di bank yang setiap saat dapat digunakan untuk membiayai kegiatan pemerintah [9].Perubahan kas dipengaruhi oleh 2 aktivitas yaitu: penerimaan kas dan pengeluaran kas. Penerimaan kas meliputi transaksitransaksi yang mengakibatkan bertambahnya saldo kas tunai dan atau rekening bank milik entitas pemerintah daerah, baik yang berasal dari pendapatan tunai, penerimaan piutang, penerimaan transfer, penerimaan pinjaman, maupun penerimaan lainnya. Sedangkan Pengeluaran kas merupakan komponen sumber daya yang sangat penting di dalam melaksanakan program pembangunan yang telah direncanakan oleh pemerintah [10].

Prosedur penerimaan dan pengeluaran kas yang baik merupakan suatu alat untuk mengkoordinasi aktivitas-aktivitas agar dapat berjalan sesuai dengan rencana yang telah ditetapkan. Untuk melaksanakan prosedur yang baik salah satu cara yang ditempuh adalah 
penyusunan sistem penerimaan dan pengeluaran berdasarkan mekanisme yang berlaku. Di era reformasi dilakukan perubahan organisasi yang disesuaikan dengan tuntutan pelayanan masyarakat. Perubahan organisasi pemerintah tersebut dilakukan dengan maksud agar pelayanan dan manajemen keuangan daerah semakin baik sehingga mudah dikontrol dan diawasi. Salah satu instansi tersebut yaitu Badan Pengelola Keuangan Aset dan Pendapatan Daerah yang bertugas untuk mengelola keuangan dan pemeliharaan terhadap aset daerah sehingga anggaran yang dimiliki daerah dapat menjalankan seluruh program yang direncanakan oleh pemerintah khususnya pada pemerintah daerah Kota Baubau yang terus memberikan dan meningkatkan pelayanan kepada pengguna dana Anggaran Pendapatan dan Belanja Daerah melalui pemberian pelayanan yang lebih cepat dengan memanfaatkan teknologi informasi dan sumber daya manusia yang profesional.

Badan Pengelola Keuangan Aset dan Pendapatan Daerah Kota Baubau sebagai instansi yang menanganikeuangan dan aset daerah menjalankan salah satu tugasnya yaitu dalam proses pencairan dana Anggaran Penerimaan dan Belanja Daerah (APBD), penatausahaan penerimaan daerah dan pertanggung jawaban pelaksanaan angaran. Badan Pengelola Keuangan Aset dan Pendapatan Daerah Kota Baubau menyajikan informasi akuntansi tentang pengendalian penerimaan dan pengeluaran kas yang merupakan suatu mekanisme pengendalian perusahaan dan alat yang efektif untuk menyediakan laporan serta bermanfaat dalam memprediksikan konsekuensi yang mungkin muncul dari berbagai pilihan aktivitas dan tindakan yang memungkinkan untuk dilakukan. Berdasarkan latar belakang yang telah diuraikan di atas, ditemukan pokok permasalahan dalam penelitian ini yaitu apakah pelaksanaan sistem informasi akuntansi penerimaan dan pengeluaran kas pada Badan Pengelola Keuangan Aset dan Pendapatan Daerah Kota Baubau sesuai dengan peraturan yang berlaku?

\section{METODE PENELITIAN}

Adapun yang menjadi sampel dari penelitian ini adalah laporan keuangan penerimaan kas berupa Laporan Realisasi Anggaran (LRA) dan laporan keuangan pengeluaran kas berupa laporan belanja dan beban pada Badan Pengelola Keuangan Aset dan Pendapatan Daerah Kota Baubau tahun 2017.

Data dalam penelitian ini dianalisis dengan menggunakan analisisdeskriptif kualitatif yaitu memberikan gambaran terlebih dahulu mengenai sistem akuntansi penerimaan kas dan pengeluaran kas yang diterapkan pada Badan Pengelola Keuangan Aset dan Pendapatan Daerah Kota Baubau kemudian disesuaikan dengan Peraturan Pemerintah (PP) Nomor 71 Tahun 2010 tentang standar akuntansi pemerintahan dan Peraturan Menteri Dalam Negeri Nomor 21 Tahun 2011 tentang pengelolaan keuangan daerah. 


\section{HASIL DAN PEMBAHASAN}

\section{a. Hasil Penelitian}

Laporan keuangan yang dihasilkan oleh Badan Pengelola Keuangan Aset dan Pendapatan Daerah (BPKAPD) Kota Baubau menggunakan sistem komputerisasi dengan menggunakan aplikasi SIMDA. Sebagaimana program aplikasi komputer yang lain, aplikasi ini memberikan banyak otomatisasi pekerjaan penyusunan laporan keuangan. Dengan otomatisasi ini, Pejabat Penatausahaan Keuangan/ fungsi akuntansi pada Badan Pengelola Keuangan Aset dan Pendapatan Daerah (BPKAPD) Kota Baubau hanya perlu mencatat transaksi dalam beberapa kertas kerja (work sheet).

Pencatatan transaksi dibagi menjadi empat jenis, yaitu Jurnal Umum (kode JU), Jurnal Penyesuaian (JP), Jurnal Penutup LRA (kode CL) dan jurnal penutup (kode CO). Pencatatan transaksi untuk setiap akun yang "di Debet" dan akun yang "di Kredit" hanya perlu diisi dengan nomor akun, selanjutnya nama akun akan terisi secara otomatis. Nama akun yang telah terisi, secara otomatis pula, akan menghasilkan buku besar (general ledger) setiap akun, neraca saldo sebelum penyesuaian, neraca saldo setelah penyesuaian serta laporan keuangan berupa Laporan Realisasi Anggaran, Laporan Operasional, Laporan Perubahan Ekuitas dan Neraca.

Laporan keuangan yang dihasilkan oleh Badan Pengelola Keuangan Aset dan Pendapatan Daerah (BPKAPD) Kota Baubau merupakan output (keluaran) dari input (masukan) berupa bukti-bukti transaksi dalam bentuk dokumen seperti Surat Perintah Pencairan Dana angsung (SP2D-LS), Surat Pertanggung Jawaban (SPJ) dan Buku Kas Umum atau formulir lainnya.

\section{Sistem Informasi Akuntansi Penerimaan Kas Pada Badan Pengelola Keuangan Asset Dan Pendapatan Daerah (BPKAPD) Kota Baubau.}

Pendapatan atau penerimaan yang dimaksud adalah pendapatan yang diterima oleh Badan Pengelola Keuangan Aset dan Pendapatan Daerah (BPKAPD) Kota Baubau selama tahun anggaran 2017. Transaksi penerimaan kas yang diteliti merupakan penerimaan kas atas dana yang akan digunakan untuk kegiatan Badan Pengelola Keuangan Aset dan Pendapatan Daerah (BPKAPD) Kota Baubau selama tahun anggaran 2017.Dalam Prosedur Penerimaan Pendapatan Daerah, pihak-pihak yang terkait adalah sebagai berikut:

1) Kepala Badan /Pengguna Anggaran.

Dalam prosedur kegiatan ini, Kepala Badan Pengelola Keuangan Aset dan Pendapatan Daerah (BPKAPD) berfungsi/berwenang untuk:

a. Menerbitkan Surat Ketetapan Pajak Daerah (SKPD dan Surat Ketetapan Retribusi Daerah (SKRD).

b. Menandatangani Surat Pertanggujawaban (SPJ).

2) Bendahara Penerimaan

Dalam prosedur kegiatan ini, Bendahara Penerimaan berfungsi/berwenang untuk: 
a. Menerima sekaligus mencocokkan uang yang disetorkan oleh Wajib Pajak/Retribusi sesuai dengan yang tertera.

b. Membuat Tanda Bukti Pembayaran (TBP)/Bukti lain yang sah dan menyerahkan kepada Wajib Pajak/Retribusi.

c. Menyetorkan uang yang diterimanya setiap hari ke Bank beserta Surat Tanda Setoran (STS) yang telah dibuat.

d. Membuat dan menyampaikan Laporan Pertanggung Jawaban untuk penerimaan satu bulan paling lambat tanggal 10 bulan berikutnya.

3) Bank

a. Bank menerima surat tanda setor (STS) dari bendahara penerimaan, lalu bank mencocokkan surat tanda setor (STS) dengan uang yang disetorkan. Apabila cocok maka bank akan membuat Nota Kredit.

b. Surat tanda setor (STS) yang telah diotorisasi oleh bank akan diserahkan kembali kepada Bendahara Penerimaan.

\section{Sistem Informasi Akuntansi Pengeluaran Kas Pada Badan Pengelola Keuangan Asset Dan Pendapatan Daerah (BPKAPD) Kota Baubau}

Kas erat hubungannya dengan pencapaian program dalam sebuah instansi melalui anggaran masing-masing bidang. Setiap bidang diberi otorisasi oleh pihak manajemen untuk mengelola anggaran dan dalam menggunakan kas. Kas yang tersedia pada Badan Pengelola Keuangan Aset dan Pendapatan Daerah (BPKAPD) Kota Baubau digunakan untuk membayar biaya operasi dinas, baik pembayaran non rutin yang dipakai untuk mengatur dan menentukan kebijakan keuangan dan operasi, maupun untuk membayar biaya lain-lain seperti biaya pemeliharaan, biaya pelaksanaan operasi, biaya kesejahteraan dan lain-lain.

Adapun prosedur pengeluaran kas pada Badan Pengelola Keuangan Aset dan Pendapatan Daerah (BPKAPD) Kota Baubau sebagai berikut:

1. Persyaratan dan Prosedur Penerbitan Surat Perintah Pencairan Dana (SP2D)

Setiap satuan kerja (satker) yang melakukan pencairan dana melalui Badan Pengelola Keuangan Aset dan Pendapatan Daerah (BPKAPD) Kota Baubau harus memenuhi persyaratan dan prosedur yang diatur, dimana bendahara mengajukan persyaratan Surat Perintah Membayar (SPM) sesuai dengan alokasi belanja atau dana yang dikehendaki yaitu:

a. Surat Perintah Membayar (SPM) Langsung Belanja Pegawai:

1) Surat Perintah Membayar (SPM) rangkap dua beserta Arsip Data Komputer (ADK)

2) Arsip Data Komputer (ADK) rekonsiliasi perubahan 
3) Daftar Perubahan data pegawai rangkap dua

4) Surat Setoran Pajak (SSP PPh Pasal 21)

5) Daftar Penerima rekening apabila lebih dari satu penerima rangkap dua

b. Surat Perintah Membayar (SPM) Langsung Non Belanja Pegawai:

1) SPM rangkap dua beserta Arsip Data Komputer (ADK)

2) Surat Setoran Pajak (SSP)

3) Daftar Penerima Rekening apabila lebih dari satu penerima rangkap dua

4) Data Pengawasan Kontrak dan Arsip Data Komputer (ADK)

5) Khusus untuk Jaminan Uang Muka harus Melampirkan :

a. Asli Surat Jaminan Uang Muka

b. Asli Surat Kuasa bermaterai

c. Asli Konfirmasi tertulis dari penerbit jaminan jaminan

c. Surat Perintah Membayar (SPM) Uang Persediaan

1) SPM rangkap dua beserta Arsip Data Komputer (ADK)

2) Surat Pernyataan dari Kuasa Pengguna Anggaran (KPA) yang dibuat sesuai format

d. Surat Perintah Membayar (SPM) Tambahan Uang Persediaan (TUP)

1) SPM rangkap dua beserta Arsip Data Komputer (ADK)

2) Surat Persetujuan tambahan uang pengganti (TUP)

e. Surat Perintah Membayar (SPM) Penggantian Uang Persediaan (GUP) Surat Perintah Membayar (SPM) rangkap dua beserta Arsip Data Komputer (ADK).

\section{b. Pembahasan}

Proses penatausahaan penerimaan keuangan daerah pada Badan Pengelola Keuangan Aset dan Pendapatan Daerah (BPKAPD) Kota Baubau, meliputi: penerimaan kas yang disetor ke rekening kas umum daerah pada setiap hari kerja ke bank pemerintah yang ditunjuk dalam hal ini adalah Bank Sultra. Setoran tersebut dianggap sah setelah pemegang kas daerah telah menerima nota kredit.

Penerimaan daerah yang disetor ke rekening kas umum daerah tersebut dilakukan oleh pihak ketiga dengan cara disetor langsung ke rekening Pemerintah Daerah Kota dalam hal ini Bank Sultra. Setelah proses penyetoran dari wajib pajak/wajib retribusi (WP/WR) tersebut, bendahara penerimaan menyelenggarakan penatausahaan terhadap seluruh penerimaan dan penyetoran berdasarkan Surat Tanda Setoran (STS) dari Bank Sultra. Berdasarkan STS ini, bendahara penerimaan membuat laporan penerimaan secara administratif.

Pada prosedur pengelolaan keuangan daerah bendahara pembantu menyetorkan hasil penagihan tersebut kepada bendahara penerimaan terlebih dahulu sebelum langsung menyetor 
ke Bank. Dari setoran tersebut, Bank Sultra menerbitkan STS dan STS tersebut disampaikan kepada bendahara penerimaan.

Hal ini dilakukan karena sesuai dengan peraturan, bahwa penerimaan berupa uang atau cek harus disetor ke rekening kas umum daerah paling lambat 1 (satu) hari kerja, kekurangan yang lain yaitu kurangnya arsip, sehingga dapat menjadi kelemahan apabila suatu saat dibutuhkannya arsip dalam proses pemeriksaan atau audit. Adapun keterlambatan dalam proses penyetoran hal ini disebabkan oleh kelalaian bendahara yang kurang memperhatikan pekerjaannya, kurangnya pengawasan dari pimpinan, dan kondisi geografis.

Sedangkan pengeluaran kas yang dilakukan oleh Badan Pengelola Keuangan Aset dan Pendapatan Daerah (BPKAPD) Kota Baubau ada yang bersifat rutin dan non rutin. Pengeluaran rutin meliputi: pembelian Alat Tulis Kantor (ATK), pembayaran gaji Pegawai Negeri Sipil (PNS), biaya perjalanan dinas serta pemeliharaan gedung. Sedangkan pembayaran non rutin meliputi: biaya pembangunan gedung, biaya perbaikan jalan, biaya pemeliaharaan jalan, biaya Pemeliharaan gedung dan lain-lain.

Badan Pengelola Keuangan Aset dan Pendapatan Daerah (BPKAPD) Kota Baubau juga mengadakan inspeksi secara mendadak terhadap aktivitas kantor terutama dalam hal penerimaan kas daerah. Dimana staf persepsi dan akuntansi secara periodik membuat rekonsiliasi bank untuk mencocokkan buku bank dengan penerimaan kas daerah yang ada pada Badan Pengelola Keuangan Aset dan Pendapatan Daerah (BPKAPD) Kota Baubau. Selain itu pada tutup tahun anggaran tanggal 31 Desember atau hari kerja terakhir maka Badan Pengelola Keuangan Aset dan Pendapatan Daerah Kota Baubau melakukan pekerjaan penyelesaian akhir laporan realisasi anggaran, arus kas, neraca dan catatan atas laporan keuangan. Untuk keperluan tersebut maka:

a. Kepala Badan selaku Kuasa Pengguna Anggaran (UAKPA) wajib membuat Laporan Realisasi Anggaran dan Neraca serta Arsip Data Komputer (ADK) yang dikelolanya.

b. Membuat Laporan Kas Posisi (LKP) harian dan mingguan

c. Membuat Laporan bulanan realisasi anggaran, arus kas dan neraca

d. Laporan yang menyangkut dengan realisasi anggaran Pendapatan dan Belanja Daerah (APBD) lainnya sepanjang belum dicatat dan masih diperlukan tetap dilaksanakan.

Agar pengeluaran kas atas beban Anggaran Pendapatan dan Belanja Daerah (APBD) baik hal ini dilihat dari pengurusan Surat Perintah Membayar (SPM) diselesaikan dalam jangka waktu 1 (satu) hari sebelum menerbitkan Surat Perintah Pencairan Dana (SPD2), terlebih dahulu dilakukan pemeriksaan terhadap Surat Perintah Membayar (SPM) untuk :

a. Menguji kebenaran perhitungan tagihan yang tercantum dalam Surat Perintah Membayar (SPM) 
b. Menguji ketersediaan dana pada kegiatan dalam Daftar Isian Penggunaan Anggaran (DIPA) yang ditunjuk dalam Surat Perintah Membayar (SPM)

c. Menguji dokumen sebagai dasar penagihan

d. Menguji surat pernyataan tanggung jawab (SPTB) mengenai tanggung jawab kebenaran pelaksanaan pembayaran

e. Menguji faktur pajak beserta Surat Setoran Pajak.

Setiap pembayaran yang dilakukan harus mendapat otorisasi dari petugas-petugas yang berwenang. Demikian juga halnya terhadap pembayaran atas beban Anggaran Pendapatan dan Belanja Daerah (APBD) yang dilaksanakan oleh Badan Pengelola Keuangan dan Aset Daerah Kota Baubau.

Adapun yang dilakukan oleh Badan Pengelola Keuangan Aset dan Pendapatan Daerah (BPKAPD) Kota Baubau sesuai dengan Permendagri Nomor 21 Tahun 2011 [11] antara lain :

a. Petugas menerima Surat Perintah Membayar (SPM) serta memeriksa dan meneliti kelengkapan dokumen

b. Mencetak dan meneliti konsep Surat Perintah Pencairan Dana (SP2D)

c. Melakukan pengujian terhadap Surat Perintah Membayar (SPM) serta memeriksa dan memaraf konsep Surat Perintah Pencairan Dana (SP2D)

d. Menerima Surat Perintah Pencairan Dana (SP2D) serta meneliti dan mencocokkan lembar ke-1 Surat Perintah Pencairan Dana (SP2D) dengan daftar penguji

e. Menerima lembar ke-1 Surat Perintah Pencairan Dana (SP2D) dan daftar penguji serta membubuhi stempel timbul pada daftar penguji.

Berdasarkan gambaran di atas, dijelaskan bahwa prosedur yangditetapkan dan dilakukan sudah baik dengan tujuan untuk memperlancar dan mempermudah suatu instansi dalam menangani pengeluaran kasnya. Dengan demikian prosedur pembayaran atas beban Anggaran Pendapatan dan Belanja Daerah (APBD) yang dilakukan oleh Badan Pengelola Keuangan Aset dan Pendapatan Daerah Kota Baubau adalah sebagai berikut:

a. Pembayaran yang dilakukan bukan melalui cek melainkan dengan menerbitkan Surat Perintah Pencairan Dana (SP2D);

b. Pembayaran yang dilakukan dengan menerbitkan Surat Perintah Pencairan Dana (SP2D) harus mendapatkan otorisasi terlebih dahulu oleh bagian yang berwenang;

c. Diadakannya pemisahan antara orang yang menerima, meneliti Surat Perintah Membayar (SPM), menerbitkan Surat Perintah Pencairan Dana (SP2D) dengan orang yang menandatanganinya.

Prosedur pengeluaran kas pada BPKAPD Kota Baubau atas beban Anggaran Pendapatan dan Belanja Daerah (APBD) yang diterapkan sudah baik karena sudah sesuai dengan Standar Akuntansi Pemerintahan (SAP) sesuai dengan Peraturan Pemerintah Nomor 71 Tahun 2010 dan 
Permendagri Nomor 21 Tahun 2011, hal ini dapat dilihat dari adanya sistem penatausahaan penerimaan kas, alur pengajuan perintah membayar dan telah melibatkan beberapa bagian dalam proses pelaksanaannya dan efesien karena dalam jangka waktu 1 (satu) hari urusan pencairan dana dapat diselesaikan dengan memenuhi persyaratan yang telah ditentukan.

\section{KESIMPULAN}

Untuk mewujudkan suatu transparansi dan akuntabilitas dalam laporan keuangan pemerintah daerah harus memenuhi Standar Akuntansi Pemerintahan (SAP) sesuai dengan Peraturan Pemerintah Nomor 71 Tahun 2010. sistem penerimaan dan pengeluaran kas telah sesuai dengan Peraturan Pemerintah Nomor 71 Tahun 2010 yakni relevan, andal, dapat dipahami dan tetap mengutamakan transparan dan akuntabilitas. Sistem penatausahaan penerimaan kas telah dilengkapi dengan dokumen, Surat Tanda Bukti Pembayaran, surat tanda setor (STS) dan Nota Kredit telah sesuai dengan Permendagri No. 21 Tahun 2011. Dimana bendahara penerimaan telah melakukan penatausahaan menggunakan surat tanda setoran (STS) yang telah diotorisasi oleh pihak Bank dan berdasarkan surat tanda setor (STS) tersebut bendahara penerimaan membuat laporan penerimaan secara administratif. Selanjutnya sistem pengeluaran kas atas beban Anggaran Pendapatan dan Belanja Daerah (APBD) yang digunakan sudah sesuai dengan peraturan yang ditetapkan. Prosedur pengeluaran atas beban Anggaran Pendapatan dan Belanja Daerah (APBD) berlangsung melalui bank. Sistem dan prosedur pengeluaran kas di Badan Pengelola Keuangan Aset dan Pendapatan Daerah Kota Baubau sudah efektif, hal ini dilihat dari penyelesaian Surat Perintah Membayar (SPM) yang masuk di Badan Pengelola Keuangan Aset dan Pendapatan Daerah Kota Baubau dapat dilakukan dalam jangka waktu 1 hari dengan memenuhi persyaratan yang telah ditentukan.

\section{SARAN}

Berdasarkan kesimpulan di atas, maka beberapa hal yang perlu mendapat perhatian, sehingga diajukan beberapa saran antara lain. Dalam memberikan tugas dan tanggung jawab kepada petugas haruslah sesuai dengan tingkat kecakapan agar memberikan prestasi kerja dan mempertahankan kejujuran dalam tugas kaitannya dengan prosedur penerimaan dan pengeluaran kas atas beban Anggaran Pendapatan dan Belanja Daerah (APBD) khususnya di Badan Pengelola Keuangan Aset dan Pendapatan Daerah (BPKAPD) Kota Baubau.Agar mempertahankan prosedur yang ada dimana setiap satuan kerja agar mengajukan Surat Perintah Membayar (SPM) sesuai waktu yang ditentukan dan dapat diselesaikan dalam jangka waktu 1 (satu) hari.

\section{DAFTAR PUSTAKA}

[1] Halim, A. 2007. Sistem Akuntansi Sektor Publik. Edisi Ketiga. Jakarta: Salemba Empat. 
[2] Republik Indonesia. Peraturan Pemerintah Nomor 71 Tahun 2010 tentang Standar Akuntansi Pemerintahan.

[3] Diana, Anastasia dan L.Setiawati. 2011. Sistem Informasi Akuntansi.Yogyakarta:Andi.

[4] Wilkinson W. Joseph. 2001. Accounting Information System. Jilid 3. Alih bahasa Agus Maulana. Jakarta: Binarupa Aksara.

[5] Bodnar, George dan W. Hoopwood. 2010. Sistem Informasi Akuntansi Edisi 9. Yogyakarta: Andi.

[6] Nordiawan, Deddi. 2007. Akuntansi Pemerintahan. Jakarta: Salemba Empat.

[7] Afiah, NN 2009, Akuntansi Pemerintahan : Implementasi Akuntansi Keuangan Pemerintah Daerah, JakartaL:Kencana Prenada Media Group.

[8] Suhanda. 2007.Akuntansi Pemerintahan. Jakarta:Salemba Empat.

[9] Komite Standar Akuntansi Pemerintahan. 2013. Buletin Teknis Standar Akuntansi Pemerintah Nomor 14: Akuntansi Kas.

[10] Janis, R.S., J. Sondakh, dan H. Sabijono. 2015. Analisis Sistem dan Prosedur Penerimaan PAD pada Dinas Pendapatan Pengelolaan Keuangan dan Aset Daerah Kabupaten Sitaro. Jurnal EMBA Volume 3 No. 1, Hal. 778 - 786.

[11] Republik Indonesia. Peraturan Pemerintah Dalam Negeri Nomor 21 Tahun 2011 tentang Pedoman Pengelolaan Keuangan Daerah. 